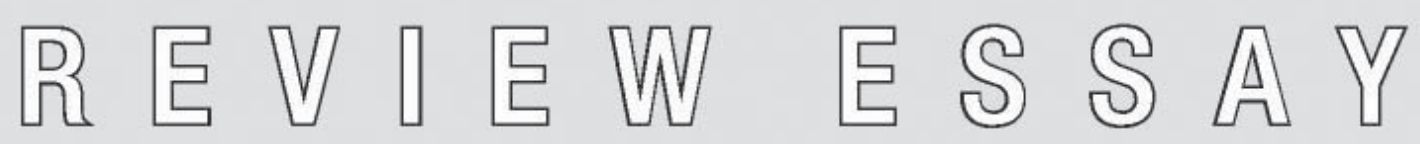
af Kim Rasmussen

\title{
Visualiserende sociologi og barndomsforskning
}

Wagner, Jon (Ed.) 1979: Images of Information. Beverly Hills/London: Sage Publication.

Prosser, Jon (Ed.) 1998: Image-based Research. London: Falmer Press.

Thomson, Pat (Ed.) 2008: Doing Visual Research with Children and Young People. London and New York: Routledge.

I 2008 udkom antologien Doing Visual Research with Children and Young People. Antologien er solidt plantet i to forskningsfelter: Barndomssociologi og visuel sociologi. To felter der de sidste 20 år efterhånden har vokset sig stærke inden for sociologiens brogede og brede genstandsområde. Begge felter må derfor siges at være veletablerede set ud fra et internationalt perspektiv. ${ }^{1} \mathrm{Om}$ det samme kan siges set ud fra en mere afgrænset dansk sammenhæng kan derimod diskuteres.

Den omtalte antologi har ud over sin placering i barndomssociologi og visuel sociologi også en placering i det pædagogiske felt, - især den mere eksperimenterede del af pædagogikken. På den måde er der tale om en interdisciplinær bog med appel til et fagligt bredt publikum.

Inden en nærmere præsentation, forsøges antologien dog først indskrevet i den visuelle sociologiske diskurs og det familiære slægtskab, den har til et par forudgående antologier om visuel sociologisk forskning. Herved vil man 
se, at feltet visuel sociologi (eller måske snarere visualiserende sociologi), har konsolideret sig over en årrække. Samtidig bliver man opmærksom på, at arbejdet med visuelle tilgange til såvel socialvidenskabelige studier generelt som til børne- og barndomsstudier, ikke er noget ganske nyt. Det ny ved den omtalte antologi er snarere, at samtlige bidrag er afgrænset til feltet børn og unge, og at der er tale om forskning med og ikke kun om børn og unge.

\section{Visuel sociologi? - en kort indkredsning}

Fotografiets opfindelse og sociologiens fremkomst er blevet henført til samme tidspunkt (Becker 1974). Fotografiets opfindelse bestemmes ofte til 1839 og Auguste Comte's 6 binds værk Cour de Philosophie Positive (hvor sociologi nævnes og bestemmes første gang) udkom i årene 1830-1842. Fra sidste halvdel af 1800-tallet finder man i stigende grad eksempler på fotografiets anvendelse i udforskningen og dokumentationen af de sociale vilkår. De fotografiske socialreportager af armod og fattigdom i New Yorks slumkvarterer omkring 1900 lavet af den danske immigrant i USA Jacob A. Riis og de dokumentarfotos af børnearbejde og udbytningen af børn i USA som Lewis Hine tog næsten samtidig, (Hine havde studeret sociologi ved Universitetet i Chicago), nævnes ofte som eksempler på en begyndende visuel sociologi.

Dette tidlige kapitel i tilblivelsen af feltet "visuel sociologi" kan næppe skrives, uden at man også kommer ind på kampen mellem de sociologer, som forsøgte at vægte samfundets visuelle aspekter og heri inddrog fotografiets muligheder, over for de som ikke ønskede at lukke fotografiet ind i sociologien. Et indblik i denne tvist får man i Clarice Stasz' vidensarkæologiske studie og bidrag til den allertidligste historie om visuel sociologi (Stasz 1979). Stasz' indsigt bygger på en analyse af udvalgte artikler fra American Journal of Sociology fra tiden mellem 1896 og 1916. I 31 artikler blev der anvendt 244 fotos. Noget der vidner om en periode, hvor fotografiet åbenbart var både velkommen og blev betragtet som et lødigt bidrag, der kunne rumme vigtige informationer. Dette ophørte imidlertid, da den positivistiske sociolog Albion Small overtog redaktørposten i 1914. Fra da af var fotos bandlyst til fordel for kausal analyse, statistiske rapporter og almene generaliseringer.

I anden halvdel af det 20. århundrede begyndte forskellige sociologer igen at arbejde med visuelle tilgange og visuelt materiale. Således har flere internationalt anerkendte og respekterede sociologer - som eksempelvis Howard S. Becker, Pierre Bourdieu, Erwing Goffman, (og Oskar Negt \& Alexander Kluge bør vel også nævnes i denne forbindelse) - i forskellige perioder og studier arbejdet med visuelle tilgange og visuelt data. ${ }^{2}$ Man kan derfor hævde, at de mere eller mindre direkte har bidraget til udviklingen af feltet "visuel sociologi". Samtidig må man ikke underkende den inspiration, senere visuelt interesserede sociologer har hentet fra det ganske nært beslægtede felt "visuel antropologi" (se fx Collier \& Collier [1967] 1986, Banks 2001). På visse måder synes lighederne større end forskellene på de sociologer og antropologer, 
der arbejder med visualisering (foto og film/video) og visuelle informationer. Noget klart og markant skel forekommer der ikke at være mellem felternes visualiseringsformer. Omvendt er der ingen tvivl om, at der hersker en vis grad af diversitet og forskellighed i både arbejdsformer og analysemåder, når man kigger på de enkelte studier. Det ser man klart i Exploring Society Photographically, hvor Howard S. Becker har samlet en helt række forskellige visuelt baserede studier (Becker 1981).

Udviklingen af "visuel sociologi", som dette felt har tegnet sig de sidste ca. 20 år, må dog i høj grad tilskrives en række andre sociologer, der synes at personificere prototypen på en visualiserende eller visuelt orienteret sociolog. Det kunne være Douglas Harper, Jon Wagner, Jon Prosser, Elizabeth Chaplin, o.a., for nu at nævne nogle af pionererne. Eller det kunne være John Grady, Paul Sweetman og andre fra en yngre forskergeneration. De har alle været involveret i flere antologier og har bidraget til at udvikle feltet. Samtidig må det påpeges, at det som holder feltet sammen, snarere synes at være passion og praksis end teoretiske dybsindigheder, der klart adskiller sig fra visuel antropologi.

\section{Images of Information}

En af de tidligste antologier, der bærer vidnesbyrd om socialvidenskabeligt arbejde med visuelle tilgange til det sociale felt, er Images of Information - Still Photography in the Social Sciences fra 1979. Den er redigeret af Jon Wagner og har et "ekstra" forord af Howard S. Becker. Becker skriver bl.a., at visual social sciences først gennem 1970'erne for alvor er begyndt at blive et synligt(!) felt. Det skyldes, at det først er i denne periode, at et større antal mennesker med interesse for både det visuelle og det sociale for alvor er begyndt at udveksle ideer, erfaringer og kritik. Becker gør samtidig opmærksom på, at et felt på dette stadium har den "fordel", at der ikke for alvor har været tid til at udvikle standardprocedurer og paradigmer, der har kunnet etablere sig. Forskerne går derfor til arbejdet med en variation af forskellige ideer, forventninger, erfaringsbaggrunde og træning/kyndighed. Det betyder, at næsten alt, hvad man gør på dette stadium, har karakter af eksperiment.

Dette er et godt signalement af de forskellige bidrag i antologien. Samtidig er det efter min vurdering et signalement, som også kan overføres på den omtalte nye antologi Doing visual research with children. I begge antologier er der en søgende attitude og friskhed over for arbejdet med at udforske socialt liv og samfund visuelt. Bagdelen ved dette kan imidlertid være (som Becker også fremhæver), at det alt sammen kan virke noget forvirrende, og at feltet måske derfor mest appellerer til forskere, der ikke lider af kaosangst, men godt kan tolerere og leve med uorden. Redaktøren Jon Wagner peger i sin indledning på, at der findes en lang tradition i naturvidenskab (arkæologi, geologi, fysik, botanik, medicin, o.s.v.) for at inddrage og bruge fotos, mens der i socialvidenskab synes at være en fundamental mangel på konsensus om 
"...the significance and meaning of photographic images". Derfor er en del af antologiens ærinde at undersøge stillfoto og den visuelle tilgang inden for socialvidenskab.

Antologien er inddelt i 5 hoveddele, der igen er inddelt i et antal forskellige kapitler. De overordnede sektioner giver et signalement af intentionen bag publikationen: Første del hedder "Research Applications", og igennem flere af kapitlerne får man et godt indblik i, at fotografi både kan være en socialvidenskabelig metode og samtidig et felt for udforskning. Adskillige af de fotograferende forskere forsøger at forstå sociale fænomener (så som: socialt udstødte mænd, skønhedsrituelle handlinger blandt kvinder, et forsvindende jødisk lokalsamfund ved Lower East Side i New York, forskellige visuelle opfattelser af et lokalsamfunds fysiske og sociale aspekter, familiefotos og foto i dagliglivet). Det sker samtidig med, at de i fotografi portrætterer steder og det sociale liv, der leves her.

Anden sektion hedder "Issues in Research", og i tre efterfølgende kapitler er der fokus på nogle af de metodologiske problemstillinger, som rejser sig i forbindelse med brugen af foto i socialvidenskab. Det drejer sig om forskerens rolle, når man på en og samme tid fotograferer og skal forstå den socialvidenskabelige værdi af de fotos, man har skabt. Det drejer sig om forskellige teknikker, man kan gøre brug af for at undgå oplagte fejl i arbejdet med at skabe og fortolke fotos. Eksempelvis kan man være flere, der fotograferer (det reducerer det subjektive og individuelle moment), og man kan følge nogle bestemte instrukser, der på en og samme tid tillader, at man har et fælles mål, men i øvrigt går til opgaven på en personlig måde, at man kan være flere om at analysere det visuelle materiale, o.a. Endelig drejer det sig om kompleksiteten ved at bevæge sig fra særlige fotografiske billeder til bestemmelser vedrørende sociale og kulturelle processer. Da de forskningsmæssige konventioner i arbejdet med visuelt materiale er relativt uudviklede, er problemstillingerne særligt fremtrædende i studier, der hviler på informationer repræsenteret i fotos.

Antologiens tredje og fjerde sektion tager afsæt i forskellige spørgsmål og problemstillinger, der rejser sig, når man bruger fotografiske billeder i undervisning rettet imod socialvidenskab. Wagner's eget kapitelbidrag i denne sektion kan tjene som eksempel. Han fortæller, at han i mange år havde haft en parallel interesse i fotografi og socialvidenskab, men det var først efter intuitivt at have følt, at man kunne lære meget om "det sociale" ved at studere og analysere fotografier, at han begyndte at eksperimentere med at bruge visuelt datamateriale i forbindelse med sin undervisning. Han udvalgte f.eks. forskellige fotos til brug i sin undervisning om samfundsmæssige fænomener. Det gjalt eksempelvis et tema som social afvigelse og social kontrol. Ud fra det visuelle materiale spurgte han systematisk de studerende, hvordan de mon troede, at livet var for de individer, der optrådte på de valgte fotografier (af kriminelle, psykisk syge, handicappede, o.a.), og som af samfundet blev 
karakteriseret som "afvigere"? De studerende blev også spurgt, hvordan de opfattede de fotograferede individer blev behandlet via forskellige institutioners sociale kontrol, og hvilken rolle sociale konventioner, økonomi, politisk ideologi spiller i forhold til at klassificere og kategorisere mennesker? Kombinationen af visuelle informationer og teoretiserende spørgsmål, der både rettede sig imod de begrebsmæssige og kontekstuelle forhold, engagerede, forvirrede og provokerede de studerende. Det satte gang i læreprocesser og kritiske tanker.

I antologiens femte og sidste sektion rettes der fokus på forskellige problemer og udsyn mod fremtidigt socialvidenskabeligt arbejde med visuelle informationer. Nogle af de ting, der blev "kæmpet med" på det tidspunkt antologien udkom, og som også formuleres rundt omkring i flere af bidragene, drejer sig om, hvorvidt visuel sociologi kan accepteres som "videnskab" eller ej. Noget af det, som diskuteres, drejer sig om, at der ikke er klarhed om data-genereringsmetoder, analysemetoder og at der ej heller findes et egentlig vokabularium. Et andet kritisk forhold drejer sig om, at visuel sociologi hviler på synssansen. Synssansen spiller afgjort en vigtig rolle i socialt liv, men samtidig er synssansen ikke en konstituerende faktor for den sociale realitet.

If we are to study social life in all its complexity, we must attend to all the senses employed by social creatures in the setting. This orientation is both essential to the empirical study of social behavior and the reason for visual sociology, siges det et sted (Cheatwood \& Stasz 1979:269).

Da Images of Information udkom i 1979, var sociologien hverken interesseret i eller orienteret imod børn og barndom på den måde, som barndomssociologien siden har afstedkommet. Man finder da heller ingen bidrag, der refererer til erfaringer med at belyse børns liv i antologien. På den måde adskiller Images of Information sig meget klart fra den nye antologi Doing research... . Ikke desto mindre er det interessant, at læse Doing visual research ... i lyset af Images... . Dels må de via interessefællesskabet om "det visuelle" betragtes som værende i familie med hinanden. Dels vidner en sammenstilling af de to antologier om, hvordan feltet for visuel sociologi har udviklet og differentieret sig. En afsluttende bemærkning i den forbindelse kunne være, at redaktøren Jon Wagner i 1999, dvs. tyve år efter at Images of Information udkom, var redaktør af et temanummer af tidsskriftet Visuel Sociologi, der faktisk ene og alene havde fokus på børn og barndom: "Seeing Kid's Worlds" var temanummerets overskrift. Heri finder man adskillelige artikler, der overbevisende og engageret beretter om de fordele og indsigter studier af børns liv fører til, når man inddrager børn og benytter eksempelvis børns egne fotos, fotoeliciterede interviews, o.lign. På den baggrund kan man hævde, at der er en høj grad af beslægtethed mellem temanummeret og Doing Visual Research with Children. 


\section{Imaged-based Research}

Det er næppe helt skævt at udpege antologien Imaged-based Research - A Sourcebook for Qualitative Researchers fra 1998, redigeret af Jon Prosser (endnu en af pionererne inden for visuel sociologi), som en central "opfølger" på Images of Information. Samtidig kan Imaged-based Research bagudskuende betragtes som et slags brohoved fra visuel sociologi til visuelle børne- og barndomsstudier. I hvert fald beretter flere af bogens bidrag om det at have en visuel tilgang til studiet af børns liv og barndom. Det gælder eksempelvis Hollida Wakefield og Ralph Underwager's kapitel: "The Application of Images in Child Abuse Investigations", Claudia Mitchell and Sandra Weber's kapitel: "Picture This! Class Line-ups, Vernacular Portraits and Lasting Impressions of School", samt Michael Schrantz and Ulrike Steinar-Löffler's kapitel: "Pupil Using Photographs in School Self-evaluation", som senere vil blive omtalt lidt mere uddybende.

Imaged-based Research rummer ellers bidrag fra enkeltpersoner, der tidligere har markeret sig i feltet (f.eks. Douglas Harper og Howard S. Becker og ligeledes Marcus Banks og Elizabeth Edwards, der tidligere har skrevet bøger om henholdsvis visuel antropologi og sociologi og visuel repræsentation), samt bidrag fra en række andre personer fortrinsvis fra den engelsksprogede del af verden. Herved kommer antologien til at fremstå som en slags præsentation af et miljø i vækst, der deler interessefællesskab og samtidig er præget af diversitet. Antologien er delt op i tre dele: 1. del, der forsøger at give et teoretisk overblik over billedbaseret forskning. 2. del, der beretter om forskningens forhold til billeder i forskningsprocessen, og endelig 3. del, som handler om eksempler på billedbaseret forskning i praksis. ${ }^{3}$

På trods af at feltet visuel sociologi fremstår mere velkonsolideret end i 1979, kæmper det stadig med at legitimere sig. Dette præger bl.a. Jon Prosser's kapitel: "The Status of Imaged-based Research". Prosser argumenterer med, at den billedbaserede forskning synes marginaliseret af den øvrige socialforskning, men også af dem, der arbejder inden for det kvalitative paradigme. Den herskende metodologi i sociologi lægger vægt på ord og ikke på billeder og visualitet. I hvert fald ikke hvis man kigger efter i de bøger, der præsenterer socialvidenskabelig metodologi. Den billedbaserede forskning synes med andre ord at være et område præget af lavstatus. Billeder bruges oftest som illustration. Billedets natur er komplekst, og dets betydning giver sjældent sig selv, men alligevel diskuterer de allerfleste metodebøger ikke, hvordan der kunne arbejdes mere seriøst med det visuelle felt og dets metoder. Prosser hæfter sig ved et paradoks: Efterhånden findes der et større kontingent af forskere i det sociale felt, der arbejder med visuelle tilgange og visuelt data. Men de har ingen "stemme", fordi der ikke er en gestalt eller noget andet, der forener billedbaseret forskning - ikke ud over a) "det visuelle" der er diffust og delvist ordløst og b) troen på at forskning kan vinde mere indsigt i de problemstillinger, der arbejdes med, ved at arbejde mere visuelt. 
Douglas Harper's kapitel "An Argument for Visual Sociology" kredser også om legitimeringsproblematikken. Harper fremhæver forskellige pointer, som de sociologiske og antropologiske studier (der trods alt findes) har bidraget til. Han ønsker, at foto betragtes som data og vil have, at sociologer skal gentænke de antagelser, de har om observation, og om hvordan man kommer fra feltobservation til analyse. Når observation opfølges af fotografering, da sker det ofte, at man chokeres, når man kigger på sine fotos. Ofte finder man ud af, at man næsten intet ved eller kun ved meget lidt om den kulturelle information, som fotografiet viser. Hvordan kan det være, at man i "rene" observationsstudier ikke chokeres over sine feltnoter? Hvordan kan det være at det først er ved konfrontationen med egne fotos, at man for alvor lægger mærke til det, man ikke lagde mærke til, mens man var i felten? Harper taler for at bruge fotos $i$ en videre dialog med levende informanter i felten. Han opfordrer til samarbejde. Altså en forskningsstrategi, der baserer sig på forskning MED snarere end OM mennesker.

Denne inddragelsesstrategi eksemplificeres i antologiens kapitel 15, hvor de østrigske forskere M. Schratz og U. Steiner Löffler beretter om skoleelever, der bruger foto til evaluering. Schrantz og Steinar Löffler har ønsket at støtte eleverne i at udforske skolens "indre verden", uden det krævede en masse verbal argumentation. Eleverne blev opfordret til at tage fotos af steder de kunne lide såvel som steder de ikke kunne lide. Fotografierne bidrog til, at børnene fik sat en dagsorden, og de gav indsigt $i$, hvordan børnene erfarede skolelivet. Hvor forskning og evaluering generelt er domineret af og baseret på det talte eller skrevne ord, dér bryder den fotobaserede metode med denne akademiske tradition. De børn, der ikke har det talte eller skrevne ord i sin magt, får nu mulighed for også at blive taget alvorlig. Forfatterne beretter i deres kapitel, hvordan man laver fotoevaluering og kommer ind på en række detaljer og erfaringer fra projektet. Bl.a. siger de, at man må forvente, at fotoevaluering kan vække stærke følelser, og at fotobaseret evaluering overskrider den akse, der ellers er bærende i skolen: at noget er rigtigt og noget andet er forkert, og at det er lærerne, der har patent på definitionerne heraf. Faktisk fik eleverne via samtalen om deres fotos stillet en række spørgsmål, om hvad der var rigtigt og forkert på skolen, og hvor lærerne ikke havde noget rigtig godt svar. I konklusionen pointeres det, at elevernes foto bidrager til at gøre ellers usynlige aspekter ved skolen synlige, og at et sådan projektet kan følges op året efter for at se, om der bliver gjort noget ved tingene.

Antologiens signalement af det frugtbare ved at have en visuel tilgang til studiet af børns liv blev bekræftet af flere andre børne- og barndomsstudier, som fandt sted i 90'erne. Feltet var vanskeligt at overskue og få overblik over "dengang", men tilbageskuende er det interessant at se, hvordan en række studier næsten samtidig og mere eller mindre uafhængigt af hinanden, har haft en visualiserende tilgang (se f.eks. Hubbard 1991, Cavin 1994, Buss 1995, Clark 1999, Orelana 1999, Ewald 2001). 


\section{Doing visual research with children}

Som nævnt i indledningen udkom antologien Doing Visual Research with Children and Young People i 2001. Adskillige af bogens kapitler bidrager både til metodologiske refleksioner over begreber om og strategier til at "inddrage børn i forskningsprocessen"/"'at lytte til børns stemme". Samtidig får læseren igennem samtlige 12 kapitler indsigt i nogle af de metodeerfaringer og metodiske vanskeligheder, der findes i feltet. Der refereres nemlig til en bred vifte af forsknings- og udviklingsprojekter, hvor forfatterne har inddraget børn og benyttet visualiserende teknikker så som børns tegninger, foto, video, collager, scrapbøger, o.lign.

Selvom bogens forfattere og indlæg indbyrdes er ret forskellige, så deler de samme anskuelse og ontologiske syn på børn og unge. Børn anskues som sociale aktører og informanter på lige fod med andre sociale aktører. Og bogens fokus er rettet mod, hvordan man kan inddrage og lave visuel forskning sammen med børn på måder, der støtter børns aktive skabelse af betydning og mening.

I forordet fortælles det, at antologien lidt tilfældigt "voksede" ud af et seminar med titlen "Engaging critically with pupils voice". Gennem 18 måneder mødtes en gruppe forskere og professionelle fra skoler, universiteter, græsrodsorganisationer og lokale myndigheder - fortrinsvis i UK - for at drøfte de forskellige måder, som elevers stemme bliver brugt og anvendt på i skoler, i netværk og i forskning. Da mange deltagere brugte visuelle metoder som middel til at udforske og repræsentere børns og unges perspektiver, blev det besluttet, at drøftelserne skulle have fokus på forbindelsen mellem "det visuelle" og "elevernes stemme". Efter seminaret tog antologiens redaktør Pat Thomson (Professor of Education \& Director of Research in the School of Education ved Universitetet i Nottingham) initiativ til bogprojektet. Hellere end at skrive en bog, der udforskede historien om visuel metodologi, ønskede hun, at bogens forfattere skulle skrive et sæt "historier fra feltet". De skulle vise det meningsfulde $\mathrm{i}$ at arbejde med billeder (image work) og fortælle noget om, hvordan dette arbejde blev udført. Bogens forfattere måtte især gerne kaste lys over nogle af de dilemmaer og udfordringer, man står overfor, når man arbejder med visuel forskning. Derfor drøfter mange af bogens kapitler problemstillinger og vanskeligheder omkring "hvad-kan-der-opstå-undervejs".

\section{Struktur og opbygning}

Antologien har først et introducerende kapitel, der præsenterer det metodiske felt: børns og unges stemmer i visuel forskning. Her drøftes begrebet "stemme". Derefter er bogen inddelt i to hoveddele. Første del hedder: "Hvorfor lave visual forskning?". Denne del består af 3 kapitler, skrevet ud fra tre forskellige videnskabsteoretiske tilgange. Catherine Burke skriver fra en kritisk pædagogisk tilgang, Ruth Leitch anlægger en hermeneutisk psykologisk tilgang til den kreative udforskning af børns narrativer gennem billeder og teg- 
ninger, mens Julianne Moss afslutter ud fra en post-strukturalistisk tilgang med fokus på visuelle metoder og policy forskning. Hver forsker diskuterer de begrundelser, de selv har lagt til grund for brugen af visuelle forskningsmetoder, og hvert kapitel bidrager til at belyse de metateoretiske, selvrefleksive og metodologiske overvejelser, der knytter sig til brugen af visuelle forskningsmetoder.

2. del hedder "Processer, muligheder og dilemmaer" og består af 8 kapitler. Hvert kapitel har afsæt i konkrete projekter, forskellige visualiserende metoder og metodeerfaringer. Fotografering og fotografi går igen $\mathrm{i}$ adskillige kapitler, men der er også kapitler om projekter, der bygger på eksempelvis visuelle scrapbøger og video-dagbøger. Generelt er kapitlerne læseværdige og interessante.

\section{Børns og unges stemme}

I det indledende kapitel fastslår Pat Thomson, at børn og unge både har evnen til og retten til at udtrykke sig om eget liv. Disse to forhold - evnen til og retten til - bringes sammen i begrebet "børns stemme". På den måde indskriver begrebet sig i det nutidige barndomsparadigme, der betragter børn som sociale aktører og medskabere af eget liv med kompetence til at udtrykke sig om dette liv. Imidlertid er der opstået en række nye problemstillinger i samme takt, som dette er blevet erkendt og accepteret: Det er illusorisk at tro, at børn og unge udgør en homogen gruppe, som kan tale med en stemme. Børn har (ligesom voksne) forskellige erfaringer, meninger og udtryksmåder. Interessen for at lytte til børns stemme var i en begyndelsesfase stor, men i dag er den opgivet til fordel for at lytte til en variation af børne-stemmer, hævdes det.

Samtidig påpeges det, at udforskningen af børns stemme er et komplekst forehavende. Man bevæger sig uvilkårligt ind på et terræn, der både rummer litterære, metaforiske og politiske aspekter. I forhold til det litterære aspekt reproducerer en stemme talen og talerens perspektiv. Metaforisk omfatter en stemme både tone, accent, stil og de følelser stemmen bærer på. Politisk set refererer en stemme til en borger og en borgers ret til at tale og at være repræsenteret. Men kompleksiteten er mere omfattende endnu. Et individ bruger ikke kun en stemme, men flere stemmer afhængig af den sociale kontekst og sted/rum. Der skelnes således mellem:

1. den autoritative stemme, der intenderer at tale på gruppens vegne,

2. den kritiske stemme, der udfordrer status quo og stereotypier ,

3. den terapeutiske stemme, der i trygge rammer drøfter smerte eller negative erfaringer,

4. forbrugerens stemme, der udtrykker præferencer vedrørende livsstil, fritid, identitet, o.lign.,

5. den pædagogiske stemme, der henviser til den civilisering og opdragelse børns og unges stemmer har været underkastet i hjemmet og i de pædagogiske institutioner, de vokser op $i$. 
På den måde gør kapitlet opmærksom på, at udforskningen af børns stemmer er kontekstafhængig og på ingen måde ukompliceret. En stemme er altid produceret og bestemt af en række forhold; magt, spørgsmål og spørgestrategier. Ligesom udlægningen af børns stemmer er afhængig af, hvem der lytter, hvad der gøres med svarene, o.lign.

Pat Thomson gør opmærksom på, at antologiens gennemgående perspektiv drejer sig om, hvordan man kan forske med børn snarere end hvordan forskning om børn kan foregå. De forskellige kapitler vidner da også om, hvordan bidragyderne på forskellig måde har involveret børn og unge som aktive co-producenter af data.

I forhold til skellet mellem "sociology of the visual" (at udforske visuelle artefakter) og "visual sociology" (at skabe visuelle artefaktor kreativt som del af forskningsprocessen), indskriver antologien sig i begge forskningsstrategier. Det visuelle forskningsfelt er i løbende udvikling. De billedbaserede metoder krydser konventionelle grænser og forståelsesformer. Samtidig må det ikke glemmes, at produktion af visuelt materiale kræver en særlig kunnen. Herunder en særlig sensibilitet og viden om både synssansen, visuelle medier samt de konkrete felter, der udforskes (reklame, vold, køn, læreprocesser, etc.).

\section{Hvorfor lave visuel forskning med børn og unge?}

Catherine Burke forsøger i kap. 2 at give et svar ud fra et projekt, hun har lavet med børn på begyndertrinet $\mathrm{i}$ en skole i Leeds. De deltagende børn blev opfordret til at udforske de rum og steder, både i skolen og derhjemme, der appellerede til leg. I forskningsprocessen brugte børnene både tegninger og engangskameraer til at dokumentere legesteder. Burke fremhæver, at projektet på den ene side viste, at børnene både havde evner til og tillagde sig rollen som "udforsker" af egen legekultur. Hun peger også på, at især foto som forskningsredskab er med til at engagere både børn og voksne. Visuelle metoder bidrager både til at belyse det felt, der studeres, og er med til at frisætte hidtil uhørte eller overhørte stemmer. Visualiseringen lokker nemlig forskellige historier frem, som ellers ikke ville være blevet fortalt. På den anden side påpeges også, at forskernes syn på børn som eksperter på egen legekultur ikke stemte overens med børnenes egne forventninger. Børns oplevelse og erfaring er, at i skolen er man elev - ikke ekspert. Skolen er således ikke en uproblematisk kontekst og et magtfrit rum at bevæge sig ind i som forsker.

I kap. 3 tager Ruth Leitch (Queens University - Nordirland) afsæt i flere projekter, hvor børn har skabt visuelle billeder (tegninger, kollager, plakater). Kapitlet beretter om, hvordan billedskabelsen kan være en tilgængelig vej til de righoldige metaforer, historier og fortællinger, der indeholder erfaringer fra børns verden. Inden for psykologien er det velkendt, at børn vedvarende fortæller historier om deres oplevelser. Derfor har der været en stigende interesse for brugen af narrative forskningsmetoder. De matcher kort og godt 
børns måde at formidle oplevelser og erfaringer på. Samtidig kan visuelle og narrative metoder ses som et middel til at give børn en stemme i forskningen. Narrative metoder har således hjulpet til at fastholde, at børn ofte har særlige perspektiver på mange af livets temaer og problemstillinger. Kapitlet argumenterer således for, at betragte børns tegninger og fortællinger som hørende til under den paraply af kreative metoder, der i dag indgår i børne- og barndomsforskningen. Svaret på spørgsmålet, hvorfor lave visuel forskning med børn og unge, synes derfor at være: Fordi visuelle metoder stimulerer børns og unges fortællinger og samtidig støtter børnene $\mathrm{i}$ at være subjekter $\mathrm{i}$ eget liv.

Julianne Moss (Melbourne University) reflekterer i 4. kap. over visuelle metoder og "policy research" - dels ud fra et projekt i en 7. klasse på en skole i Tasmanien, dels ud fra andre policystudier.

Moss insisterer på metoder, der kan bruges i small-scale-studier, og som samtidig kan inddrages som pædagogisk metode af pædagoger og lærere. På den måde argumenterer hun indirekte for brugen af visuelle metoder, som mediepædagogisk praksis. Som hun siger:

Jeg forstår visuelt data, som noget, der gør det muligt at samle og fastholde det komplicerede ved det levede livs oplevelser og kulturelle betydning via billeder.

Herefter påpeger hun, at form og indhold er uadskilleligt. Samtidig kan billeders formudtryk granskes gennem spørgsmål som: Hvad er meningen med denne vinkel, dette motiv, disser farver, denne fremtrædelse, - mens billeders indhold kan granskes via spørgsmål som: Hvem har produceret dette? Ud fra hvilke intentioner og motiver? Hvem er adressaten? En af de karakteristiske ting ved kapitlet er alle de selvkritiske spørgsmål og den ydmyghed, som hun lægger for dagen.

\section{Processer, muligheder og dilemmaer}

De resterende kapitler viser mangfoldigheden af metoder, processer, muligheder og barrierer, som visuelle og deltagende forskningsprojekter afstedkommer. Hvert kapitel skal ikke omtales. Men et kig på nogle stykker kan give et indtryk af, hvad der fokuseres på, og hvad der drøftes. I kapitel 5 drøfter Kaye Johnson (Department for Education and Children's Services - Adelaide, South Australia) erfaringer med: "At lære børn at bruge visuelle forskningsmetoder". Hun er især interesseret i den betydning børn tillægger deres skole. Børn erfarer steder anderledes end voksne (fordi de bruger stederne anderledes). I sin forskning forsøger hun at værdsætte børns viden om de steder, de relaterer sig til og ved noget om. Hendes studie består af tre sammenkædede projekter: Et hvor hun inviterede børnene til via fotografering at vise de steder, de relaterede sig til. Et andet hvor børnene i smågrupper blev 
opmuntret til at fortolke deres fotos. Og et tredje der havde til formål at undersøge stederne kritisk ved at forsøge at kigge bagom det visuelle materiale. I det 6. kapitel af Marisol Clark-Ibanez (Dept. of Sociology - California State University, San Marcos) rettes focus på køn og at være en uregerlig elev. Projektet drejer sig om "bad girls", hvis stemmer bliver bragt frem og hørt via fotoeliciterede interviews baseret på elevernes egne fotos med engangskamera. Metoden indskriver sig i et årelangt feltstudium af en skoleklasse, som udgør den ene del af forskningskonteksten. Den anden del består i elevernes egne fotografier af det, som er vigtigt for dem, hvorefter der blev lavet foto-eliciterede interviews i børnenes hjem og med forældrenes tilladelse. Der findes kun få studier af utilpassede piger, og studiet kommer derved til at fremstå som et tilstræbt supplement til de studier, hvor rebelske drenge har været $\mathrm{i}$ fokus eller er kommet til orde. Det frembragte datamateriale forekommer både tankevækkende og interessant.

I det 7. kapitel fortæller Sara Brag (Academic Fellow in Child and Youth Studies - Open University) \& David Buckingham (Prof. of Education - Inst. of Education, London University) om deres projekterfaringer fra et studie, hvor de har benyttet: "Scrapbøger som kilde i medieforskning med unge". Dette studie fortæller dels noget om de unge's forhold til mediernes fremstilling af kærlighed, sex og venskabsforhold. Dels forholder de sig også til "grænserne" for, hvad forskere kan se og udtale sig om i denne type af kvalitative studier. Som de siger:

Vi ønskede at de unge skulle lære os om de medieformer og materialer, vi ikke selv har noget særligt kendskab til, og scrapbøgerne viste sig at være en metode og en form, der gav et vist indblik i aktuelle og kønsbestemte medieerfaringer, samtidig med at alt, hvad der blev sagt og fortalt, ikke blev taget for pålydende.

I kapitel 11, der har titlen: "At blive "set", at være "hørt"' fortæller Ian Kaplan (fra School of Education - University of Manchester) om ét projekt ud af fem, der fokuserede på elevers stemme. I kapitlet berettes om elever med "særlige behov"/læringsvanskeligheder, og især er der fokus på de potentialer, som deltagelse via et fotoprojekt indeholder, ikke mindst for den omtalte gruppe elever, som typisk kun har meget lidt eller ingen kontrol over, hvor og hvordan deres forståelse af og perspektiver på skoleforhold bliver repræsenteret. Almindeligvis forbliver de usete og uhørte.

Efter endt læsning sidder man tilbage med et godt indtryk af potentialerne ved den visuelle og deltagerinviterende udforskning af børn og unges liv. Ligeledes er man blevet godt informeret om mange af de både positive og negative erfaringer, man kan gøre. Der tegner sig også et billede af en særlig type forskning - nemlig den, der ligger i grænselandet mellem pædagogikkens: At løse en opgave, og den socialvidenskabelige: at finde forskningsmæssige 
svar på, hvordan verden erfares og ser ud fra de andres perspektiv. Samtidig er antologien et vidnesbyrd om, hvordan visuelle metoder ikke kun afføder nye former for datamateriale, men også indvirker på relationer og positioner mellem forskere og deltagere.

\section{Noter}

1. Barndomssociologer (og andre børne- og barndomsforskere med tilgrænsende fagligheder) har siden 90'erne produceret en stribe indflydelsesrige bøger, ligesom de kommer til orde i bestemte tidsskrifter (Childhood, Child and Society, o.a.). Tilsvarende har en række "visuelle sociologer/antropologer" produceret en markant litteratur og samlet sig omkring bestemte tidsskrifter (f.eks. Visuel Studies) og i bestemte organisationer (f.eks. IVSA - International Visual Sociological Association).

2. Nogle håndplukkede eksempler kunne være Lewis Hine (1874-1940), som tidligt fandt ud af at fotografiet snarere end ordet, var det mest effektive medium til at udtrykke viden om og kritik af børnearbejde, Erwing Goffman (1922-1980), der med Gender Advertisement fra 1979 kan siges at have været med til at etablere en sociologisk orienteret reklameforskning, eller Pierre Bourdieu (1930-2002), hvis interesse for amatørfotografi/den jævne kunst resulterede i både publikationen Photography - A Middle-brow Art [1965] 1990 og artikler om amatørfotografi, eller Oskar Negts (1930) \& Alexander Kluges (1932) brug af det visuelle og collage-agtige i forbindelse med deres interesse for sammenhængs-forhold/helhedsorientering - se Geschichte und Eigensinn (1981).

3. Efter Imaged Based Research er der med korte mellemrum blevet publiceret en række antologier, der også bør nævnes, fordi de har bidraget til at konsolidere feltet og arbejdet med samfundets og kulturens visuelle aspekter, omend listen ikke gør krav på at være fuldstændig.

- I 2000 udkom: Researching the Visual, redigeret af Michael Emmison \& Philip Smith.

- $\quad$ I 2001 udkom: Handbook of Visual Analysis, af Theo van Leeuwen \& Carey Jewitt med bidrag fra eksempelvis Malcolm Collier, Martin Lister \& Liz Wells. Flere af bidragene i håndbogen er baseret på et semiotisk grundlag, men der er også kapitler baseret på psykoanalyse og etnometodologi.

- I 2004 udkom: Picturing The Social Landscape: Visual Methods and The Sociological Imagination, redigeret af Caroline Knowles \& Paul Sweetman, med bidrag af bl.a. John Grady, Douglas Harper, Les Back og Howard S. Becker.

- I 2004 udkom i Sverige: Bild och samhälle, redigeret af Patrik Aspers, Paul Fuehrer \& Arni Sverrison.

\section{Anden litteratur}

Banks, Markus 2001: Visual Methods in Social Research. London, Thousand Oaks, New Delhi: Sage Publications.

Becker, Howard S. 1974: "Photography and Sociology". In: Studies in the Anthropology of Visual Communication, 1. pp. 3-26.

Becker, Howard S. 1981: Exploring Society Photographically. Evanston, Illinois: Mary and Leigh Block Gallery. Northwestern University.

Buss, Shirl 1995: “Urban Los Angeles from Young People's angle of vision". In: Children's Environment, 12 (3): pp. 340-351.

Cavin, Erica 1994: "Search of the Viewfinder: A study of a child's perspective". In: Visual Sociology 9, (1) pp. 27-41.

Chaplin, Elizabeth 1994: Sociology and Visual Representation. London and New York: Routledge. 
Clark, Cindy D. 1999: “The Autodriven Interview. A Photographic Viewfinder into Children's Experience". In: Visual Sociology, vol. 14. pp. 39-50.

Collier, John \& Collier, Malcolm [1967] 1986: Visual Antropology. Photography as a Research Method. Albuquerque: University of New Mexico Press.

Ewald, Wendy 2001: I Wanna Take Me a Picture. Teaching Photography and Writing to Children. Coauthored by Alexandra Lightfoot. Boston: A Lyndhurst book. Beacon Press.

Hubbard, Ron 1991: Shooting back - a Photographic View of Life by Homeless Children. San Francisco: Chronicle Books.

Orellana, Majocie F. 1999: "Space and Place in an Urban Landscape. Learning from Children's views of Their Social Worlds". In: Visual Sociology, vol. 14. pp. 73-89.

Stasz, C. 1979: "The Early history of Visual Sociology". In: Wagner (Ed.): Images of Information. Beverly Hills/London: Sage Publications.

Kim Rasmussen

E-mail: kimras@ruc.dk 